\title{
Auxin Production Is a Common Feature of Most Pathovars of Pseudomonas syringae
}

\author{
Eric Glickmann, ${ }^{1}$ Louis Gardan, ${ }^{2}$ Sylvie Jacquet, ${ }^{2}$ Shafik Hussain, ${ }^{2}$ Miena Elasri, ${ }^{1}$ Annik Petit, ${ }^{1}$ and \\ Yves Dessaux ${ }^{1}$ \\ ${ }^{1}$ Institut des Sciences Végétales, Centre National de la Recherche Scientifique, Avenue de la Terrasse, F- \\ 91198 Gif sur Yvette Cedex; ${ }^{2}$ Station de Pathologie Végétale, Institut National de la Recherche \\ Agronomique, 42, rue Georges Morel, B.P. 57, F-49071 Beaucouzé Cedex, France \\ Accepted 3 November 1997.
}

\begin{abstract}
We investigated indole-3-acetic acid (IAA) production by 57 pathovars of Pseudomonas syringae and related species. Most of those analyzed produced IAA, especially in the presence of tryptophan. Eight strains produced high IAA concentrations in the absence of Trp. The iaaM and iaaH genes of $P$. savastanoi pv. savastanoi were detected in a limited number of strains only, including the eight abovementioned strains. Thus, IAA synthesis in most assayed strains of $P$. syringae and related species does not involve genes highly similar to iaaM and iaaH. In contrast, the iaa L gene encoding an IAA-lysine synthase was detected in most pathovars, and was often found on plasmids.
\end{abstract}

Additional keywords: Azospirillum, Erwinia, plant growth regulators, plant pathogens.

\footnotetext{
Most of the bacterial strains belonging to the Pseudomonas syringae group are plant pathogens. For years, the taxonomic position of this group and that of its constitutive members relied on a limited number of characters, including pathogenicity-related characters (Schaad 1982; Young et al. 1992). However, the emergence of numerical (Sneath 1984) and molecular techniques (Johnson 1984; Wayne et al. 1987; Woese 1992) led to a complete revision of the taxonomy of this group of bacteria. At present, Young et al. (1996) have listed over 50 pathovars of $P$. syringae, three pathovars of $P$. savastanoi, and three related species ( $P$. amygdali, $P$. ficuserectae, and $P$. meliae) that fall within nine genomospecies (Gardan et al. 1997). Each genomospecies, which may eventually be regarded as a new species, contains strains exhibiting at least $70 \%$ DNA/DNA homology with the relevant type strain(s). As a consequence, several pathovars of $P$. syringae and related species have already been, or will be, renamed. For instance, $P$. syringae pv. savastanoi became $P$. savastanoi pv. savastanoi, $P$. syringae pv. glycinea became $P$. savastanoi pv. glycinea, and $P$. syringae pv. phaseolicola became $P$. savastanoi pv.
}

Corresponding author: Yves Dessaux; Telephone: 331698236 90; Fax: 331698236 95; Department Office: 331698236 96; E-mail: Yves.Dessaux@isv.cnrs-gif.fr

Current address of Eric Glickmann: Department of Plant Pathology, University of California at Riverside, Riverside 92521, U.S.A. phaseolicola. In this report, we will (i) retain only the current approved names for these plant pathogenic bacteria (Young et al. 1996), (ii) collectively term strains belonging to $P$. savastanoi and $P$. syringae pathovars and their related species as the $P$. syringae group, and (iii) include $P$. viridiflava with the three above-mentioned $P$. syringae-related species (Gardan et al. 1997). However, the $P$. tremae genomospecies, which includes only $P$. syringae pv. tremae strains, is excluded from this study since its taxonomic position still remains open to discussion (Gardan et al. 1997).

For P. savastanoi pv. savastanoi strains, pathogenicity implies biosynthesis of plant growth regulators. The synthesis of hormones such as cytokinins and indole-3-acetic acid (IAA) leads to the formation of the characteristic knots on olive and oleander (Wilson 1935; Smidt and Kosuge 1978). In P. savastanoi pv. savastanoi oleander strains, IAA biosynthesis proceeds from L-tryptophan (Trp) to IAA via indole-3 acetamide (IAM). Two enzymes, a Trp-2 monoxygenase and an indoleacetamide hydrolase, are involved in this pathway (Kosuge et al. 1966). The synthesis of these enzymes is determined by two genes, called iaaM (for the monooxygenase) and $i a a \mathrm{H}$ (for the hydrolase) (Comai and Kosuge 1980, 1982; Comai et al. 1982). In P. savastanoi pv. savastanoi olive strains, iaa $\mathrm{M}$ and $i a a \mathrm{H}$ genes are located on the chromosome (Comai et al. 1982). These genes were cloned and sequenced (Comai et al. 1982; Palm et al. 1989) from a 52-kb plasmid of an oleander strain (Comai and Kosuge 1980, 1982; Comai et al. 1982). The iaa $\mathrm{M}$ and iaa $\mathrm{H}$ genes show 54 and $38 \%$ similarity, respectively, to tms 1 and $t m s 2$, two genes responsible for IAA biosynthesis in the plant cells infected by Agrobacterium tumefaciens (Gielen et al. 1984; Klee et al. 1984; Yamada et al. 1985). Strains of $P$. savastanoi pv. savastanoi pathogenic on oleander also convert IAA to indole-3 acetyl- $\varepsilon$ L-lysine (IAA-Lys), a compound that is biologically less active than IAA (Hutzinger and Kosuge 1968) as estimated by the coleoptile elongation assay (Nitsch and Nitsch 1956; Surico and Iacobellis 1992). This conversion involves the enzyme IAA-lysine synthase, whose synthesis is encoded by the iaaL gene (Glass and Kosuge 1986, 1988; Roberto et al. 1990). In P. savastanoi pv. savastanoi oleander strains, this gene is located on the plasmid within 2,000 bp of iaaM and iaaH (Glass and Kosuge 1986). 
Previous studies performed on a very limited number of strains of $P$. syringae pv. syringae, $P$. savastanoi pv. phaseolicola, $P$. syringae $\mathrm{pv}$. tabaci, and $P$. syringae pv. tomato revealed that some of these produce IAA, especially when Trp is added to the culture media (Fett et al. 1987; Gardan et al. 1992). Genes responsible for IAA synthesis in P. syringae pv. syringae were cloned with a probe overlapping the $i a a \mathrm{M} / i a a \mathrm{H}$ genes of $P$. savastanoi pv. savastanoi (White and Ziegler 1991). The deduced amino acid sequences of iaaM and iaaH of $P$. syringae pv. syringae share over $90 \%$ identity with the amino acid sequences deduced from the respective ia homologues of P. savastanoi pv. savastanoi (Mazzola and White 1994). In most other pathovars, it is not known whether these genes are present (Ziegler et al. 1987; White and Ziegler 1991). However, the presence of $i a a M$ and $i a a H$ homologous sequences has been reported in P. savastanoi pv. glycinea (F. F. White and M. Mazzola, unpublished; quoted in Mazzola and White 1994). Furthermore, Gardan et al. (1992) showed that strains of $P$. syringae pv. tomato and $P$. savastanoi pv. phaseolicola produced compounds reacting with a Salkowski's formulation that is used for the colorimetric detection of indolic compounds such as auxin (Gordon and Weber 1951), though sequences similar to the $i a a \mathrm{M} / i a a \mathrm{H}$ genes of $P$. savastanoi pv. savastanoi were not detected in these two strains. These results prompted us to examine the production of IAA by a wide range of strains of the $P$. syringae group. The results reported here deal with 57 pathovars of $P$. syringae, $P$. savastanoi, and related species belonging to eight out of nine genomospecies defined by Gardan et al. (1997). Interestingly, these results show that most assayed strains do produce IAA. In these strains, however, genes involved in auxin production are not highly homologous to the $i a a \mathrm{M}$ and $i a a \mathrm{H}$ genes of $P$. savastanoi, since these sequence were not detected in approximately $80 \%$ of the $P$. syringae pathovars.

Fifty-six strains of the $P$. syringae group (out of the 57 strains of our collection) were examined for IAA production with high-pressure liquid chromatography analysis of an ethyl acetate extract of the culture supernatants, according to a procedure that we developed (E. Glickmann, M. Elasri, A. Petit, and Y. Dessaux, unpublished). Unless otherwise stated, all strains were grown at $25^{\circ} \mathrm{C}$ in modified King B medium (KB; King et al. 1954), which consisted of the following: proteose peptone no. 3 (Difco-OSI, Elancourt, France), $10 \mathrm{~g} ; \mathrm{K}_{2} \mathrm{HPO}_{4}$, $1.15 \mathrm{~g} ; \mathrm{MgSO}_{4} \cdot 7 \mathrm{H}_{2} \mathrm{O}, 1.5 \mathrm{~g}$; and glycerol $1.5 \%$ (vol/vol); $\mathrm{pH}$ was adjusted to 7.2 with $\mathrm{HCl} 2 \mathrm{~N}$. When appropriate, $0.5 \mathrm{~g}$ of Trp per ml was added to the media. All liquid cultures were aerated by shaking. Results presented in Table 1 are average values obtained from at least two independent experiments. In the absence of Trp in the growth medium, IAA concentrations were generally low (average value $1.3 \mu \mathrm{g} / \mathrm{ml}$ ). No IAA or only trace amounts were detected in the supernatant of 26 out of the 56 assayed strains while five strains, 1392 (P. syringae pv. syringae), 2339 (P. syringae pv. aceris), 2897 (P. syringae pv. myricae), 1657 ( $P$. syringae pv. maculicola), and 10971t ( $P$. syringae pv. ribicola), produce IAA amounts greater than 5 $\mu \mathrm{g} / \mathrm{ml}$ and three strains, 1670 (P. savastanoi pv. savastanoi), 2341 ( $P$. syringae pv. cannabina), and 2899 (P. syringae pv. photiniae), synthesized IAA at concentrations over $2 \mu \mathrm{g} / \mathrm{ml}$. In presence of Trp, all assayed Pseudomonas strains produced auxin in variable concentrations, the exceptions being $P$. syringae pv. ciccaronei strain 2342 and $P$. syringae pv. persicae strain 1573. The low level of IAA in the culture supernatant of strain 1573 could be related to its very poor growth in liquid $\mathrm{KB}$ medium. In agreement with this hypothesis, another $P$. syringae pv. persicae strain (CFBP1067), which grew as well as other assayed Pseudomonas strains in $\mathrm{KB}$ medium, produced IAA. Except for the two above-mentioned strains, in the presence of Trp, IAA concentrations in culture supernatants range from 0.7 to $69.7 \mu \mathrm{g} / \mathrm{ml}$, the average value being $9.5 \mu \mathrm{g} / \mathrm{ml}$. A few strains such as 1392 (P. syringae pv. syringae), 2339 (P. syringae pv. aceris), 1670 (P. savastanoi pv. savastanoi), 2215 ( $P$. syringae pv. delphini), 1657 ( $P$. syringae pv. maculicola), 10971t (P. syringae pv. ribicola), and 2341 ( $P$. syringae pv. cannabina) generate high amounts of IAA. These include all five strains that produce IAA concentrations higher than $5 \mu \mathrm{g} / \mathrm{ml}$ without added Trp in their growth media. Among other assayed gram-negative bacteria (Table 1), only Erwinia herbicola pv. gypsophilae strain 11141, which harbors genes homologous to the $i a a \mathrm{M} / i a a \mathrm{H}$ genes of $P$. savastanoi pv. savastanoi (Clark et al. 1993), and Agrobacterium strains C58 and K84 produce IAA, a result consistent with a previous report (Liu and Kado 1979).

We investigated the presence of sequences similar to iaaM and $i a a \mathrm{H}$ genes in the genome of 55 strains of the P. syringae group. This was assessed by Southern blot hybridization on genomic DNA preparations obtained by a modification of the protocol of Dhaese et al. (1979). The iaaM/iaaH probe consisted of a 2.2-kb BamHI-EcoRI fragment from the plasmid pLUC2 that contains most of the $i a a \mathrm{M}$ and $i a a \mathrm{H}$ operon of $P$. savastanoi pv. savastanoi (Comai and Kosuge 1982). The iaa $\mathrm{L}$ probe generated from pLG87 was a 1,301-bp PleI restriction fragment overlapping the only (but complete) sequence of the open reading frame ORF2 of the iaa $\mathrm{L}$ region (this open reading frame is sufficient to confer IAA-lysine synthase activity upon the recipient host; Glass and Kosuge 1986; Roberto et al. 1990). Probes were labeled by random incorporation of a digoxygenin-modified nucleotide (Boehringer-Mannheim, Mannheim, Germany). DNA was transferred onto a Hybond-N membrane (Amersham-Life Science, les Ulis, France) as previously described (Ausubel et al. 1989; Sambrook et al. 1989). Hybridization and detection of heteroduplex were made according to the manufacturer's instructions as modified by Dessaux et al. (1995) and VaudequinDransart et al. (1995). Hybridization and washes were done at $61.5 \pm 0.5^{\circ} \mathrm{C}$. Washes were performed in a solution of $2 \times \mathrm{SSC}$ ( $1 \times \mathrm{SSC}$ is $0.15 \mathrm{M} \mathrm{NaCl}$ plus $0.015 \mathrm{M}$ sodium citrate), $0.1 \%$ sodium dodecyl sulfate. This set of conditions should allow the detection of probe-DNA homology over $75 \%$. Detection was performed with the NBT/X-pho colorimetric system or the more sensitive chemiluminescent substrates Lumigen-PPD and CSPD (Nucleic Acid Detection kit, BoehringerMannheim, Mannheim, Germany). Results are presented in Table 1.

Sequences homologous to the $i a a \mathrm{M} / i a a \mathrm{H}$ genes of $P$. $s a$ vastanoi pv. savastano $i$ were detected in only 11 strains, even though the experiment was performed under low stringency hybridization conditions. These strains belong to the genomospecies 1 ( $P$. syringae pvs. syringae and aceris), 2 ( $P$. savastanoi pv. glycinea, $P$. syringae pvs. myricae and photiniae, and $P$. amygdali), 3 (P. syringae pvs. maculicola, ribicola, and viburni), and 9 (P. syringae pv. cannabina). Interestingly, most of these strains (in pvs. syringae, aceris, savastanoi, myricae, 
Table 1. Production of indole-3-acetic acid (IAA) by various Pseudomonas syringae pathovars and the relationship with the presence or the absence of the $i a a \mathrm{M}, i a a \mathrm{H}$, and $i a a \mathrm{~L}$ genes

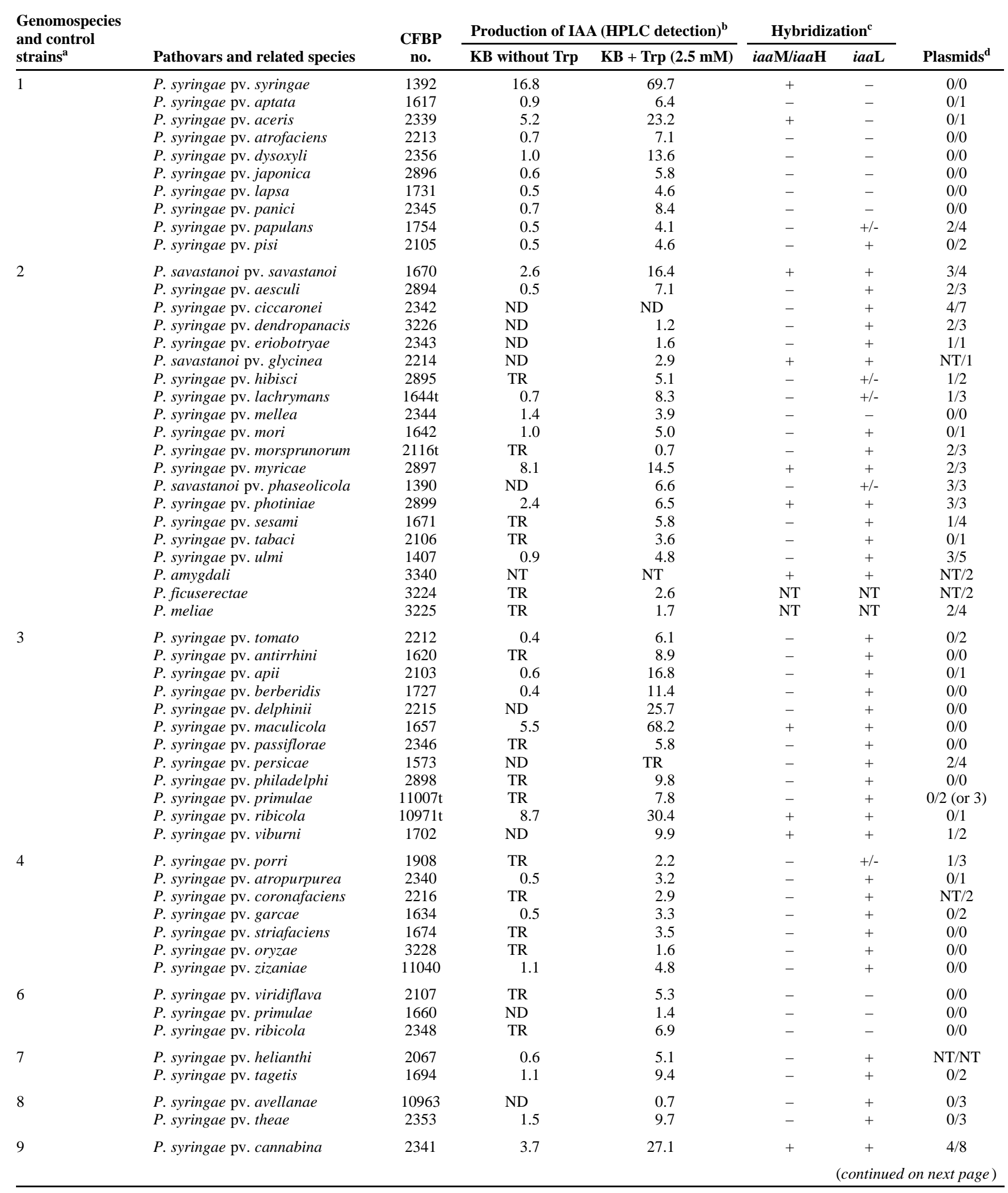


Table 1. (continued from previous page)

\begin{tabular}{|c|c|c|c|c|c|c|c|}
\hline \multirow{2}{*}{$\begin{array}{l}\text { Genomospecies } \\
\text { and control } \\
\text { strains }^{\mathrm{a}}\end{array}$} & \multirow[b]{2}{*}{ Pathovars and related species } & \multirow{2}{*}{$\begin{array}{c}\text { CFBP } \\
\text { no. }\end{array}$} & \multicolumn{2}{|c|}{ Production of IAA (HPLC detection) ${ }^{\text {b }}$} & \multicolumn{2}{|c|}{ Hybridization $^{c}$} & \multirow[b]{2}{*}{ Plasmids $^{\mathrm{d}}$} \\
\hline & & & KB without Trp & KB $+\operatorname{Trp}(2.5 \mathrm{mM})$ & iaaM/iaaH & $i a a \mathbf{L}$ & \\
\hline & Agrobacterium tumefaciens & C58 & ND & 1.3 & - & - & NT \\
\hline & Agrobacterium sp. (biovar II) & K84 & TR & 2.3 & - & - & NT \\
\hline & Erwinia herbicola pv. gypsophilae & 11141 & ND & 4.0 & + & - & NT \\
\hline & Alcaligenes faecalis & 15 & ND & ND & - & - & NT \\
\hline & Escherichia coli & 10161 & ND & TR & - & - & NT \\
\hline
\end{tabular}

${ }^{a}$ All Pseudomonas strains were from the Collection Française des Bactéries Phytopathogènes (CFBP, INRA, Angers, France). Agrobacterium strains were taken from the collection of our laboratories. Escherichia coli strain 10161 and Erwinia herbicola pv. gypsophilae strain 11141 containing $i a a \mathrm{M} / i a a \mathrm{H}$ genes were obtained from Louis Gardan. Genomospecies were as defined by Gardan et al. (1997).

${ }^{b}$ IAA concentrations were determined by high-pressure liquid chromagraphy (HPLC) from bacterial culture supernatants extracted with ethyl acetate (E. Glickmann, M. Elasri, A. Petit, and Y. Dessaux, unpublished). IAA concentrations are expressed in $\mu \mathrm{g}$ of bacterial supernatant per ml. Abbreviations: NT, not tested; ND, no IAA detected; TR, trace amounts $(\chi \leq 0.3 \mu \mathrm{g} / \mathrm{ml})$ of IAA detected.

${ }^{\mathrm{c}}$ Presence of $i a \mathrm{M} \mathrm{M} / i a a \mathrm{H}-$ and $i a a \mathrm{~L}-$ related sequences as assessed by Southern blot hybridization (for conditions see text): -, no signal; +/-, weak signal; + , strong signal.

${ }^{d}$ Plasmids hybridizing with $i a a \mathrm{~L} /$ total number of plasmids. Plasmid separation from $P$. syringae strains was performed as indicated in the text with a modification of the procedure by Wheatcroft et al. (1990). Hybridization with the iaa $\mathrm{L}$ probe was performed on Southern blots of native plasmid DNA under conditions similar to those used to investigate the presence of $i a a \mathrm{M}, i a a \mathrm{H}$, and $i a a \mathrm{~L}$ sequences in restricted genomic DNA preparations (see text).

photiniae, maculicola, ribicola, and cannabina) are among those that produced high amounts of IAA in the absence or in the presence of Trp. Our results also indicate that $81 \%$ of the assayed Pseudomonas strains that produce IAA do not harbor sequences highly related to the $i a a \mathrm{M} / i a a \mathrm{H}$ genes. Therefore, IAA synthesis by these strains appears to be controlled by genes other than those homologous to the $i a a \mathrm{M} / i a a \mathrm{H}$ probe. Control hybridizations also were performed on genomic DNA extracted from several gram-negative bacteria (Table 1). As expected, no sequence homologous to the $i a a \mathrm{M} / i a a \mathrm{H}$ genes was detected in A. faecalis and Escherichia coli whereas the $i a a \mathrm{M} / i a a \mathrm{H}$ genes of the $E$. herbicola control strain generated clear hybridization signal with the probe. The tms $1 /$ tms 2 genes of the C58 T-DNA were not detected under our experimental conditions. This observation is in agreement with the expected detection threshold (approximately 75\%) provided by our experimental conditions.

We also investigated the presence of iaaL-sequences in the genomes of 55 strains of the $P$. syringae group by Southern blot hybridization. Results are presented in Table 1 for the Pseudomonas strains and for the gram-negative control strains. Remarkably, 43 out of 55 assayed Pseudomonas strains possess sequences related to the iaa $\mathrm{L}$ probe, but the results vary according to the genomospecies. iaaL-related sequences were detected in all pathovars of the genomospecies 3 (12 strains) and 4 (7 strains), and in most assayed strains (17 out of 18) of genomospecies 2 . In contrast, only two out of 10 strains of the genomospecies 1 appear to harbor iaaL-related sequences and none of the three assayed strains of the genomospecies 6 contain iaaL-related sequences. No iaaL-related sequences were detected in the genomes of E. herbicola strain 11411, A. tumefaciens C58, A. faecalis 15, and E. coli 10161 (Table 1). Related sequences also were not detected in Rhizobium meliloti strain Rm41 and several other Pseudomonas strains belonging to $P$. fluorescens, $P$. putida, $P$. corrugata, and $P$. stutzeri (data not shown). Interestingly, the presence of iaaL-related sequences is not correlated with the presence of the iaa $\mathrm{M} / i a a \mathrm{H}$ homologues in the assayed Pseudomonas strains as deduced from the results obtained with strains of the $P$. syringae pvs. syringae and aceris.
The location of the $i a a \mathrm{M}, i a a \mathrm{H}$, and $i a a \mathrm{~L}$ genes in the bacterial genome was investigated by Southern blotting of native plasmid DNA preparations. Plasmid separation was performed by a modification of the protocol designed by Wheatcroft et al. (1990) and Geniaux et al. (1993) for the separation of Rhizobium meliloti plasmids in horizontal gel. One milliliter of an overnight culture in $\mathrm{KB}$ medium at $\mathrm{OD}_{600}=0.3$ was centrifuged $\left(8,000 \times g, 5 \mathrm{~min}, 4^{\circ} \mathrm{C}\right)$, and the pellet resuspended in 1 $\mathrm{ml}$ of $5 \mathrm{M} \mathrm{NaCl}$. Fifty microliters of $5 \% \mathrm{Na}$-Sarcosyl was added, and gently mixed by inverting the tube. The mixture was immediately centrifuged under the above conditions, and the supernatant was discarded. The pellet was then resuspended and the extraction was carried out as indicated by Wheatcroft et al. (1990). All operations were performed on ice. Plasmid separation was achieved in a $0.7 \%$ agarose gel, during $5 \mathrm{~h}$ at $5 \mathrm{~V} / \mathrm{cm}$. The buffer was cooled at $0^{\circ} \mathrm{C}$ with ice and re-circulated from one side of the tank to the other. Plasmids were detected in 37 out of 56 assayed Pseudomonas strains (Table 1). The number of plasmids ranged from 0 (for instance in the $P$. syringae pv. syringae strain 1392) to eight (in the $P$. syringae pv. cannabina strain 2341). Nineteen out of 20 assayed strains of the genomospecies 2 harbor plasmid(s), but only half of those from the genomospecies 1,3 , and 4 possess plasmids, while no plasmids were detected in the strains of genomospecies 6 .

Southern blots performed with the iaa $\mathrm{M} / i a a \mathrm{H}$ probe involved the only strains that genomic DNA preparations generated a hybridization signal with this probe (see Table 1). Results (not shown) indicate that the iaa $\mathrm{M} / \mathrm{iaa} \mathrm{H}$ genes are most often located on the chromosome of these strains. Thus, $P$. savastanoi strain 1670 isolated from olive likely harbored chromosomal copies of the $i a a \mathrm{M} / i a a \mathrm{H}$ genes as already observed for other P. savastanoi strains isolated from this host plant (Comai et al. 1982; Glass and Kosuge 1986; Palm et al. 1989). The chromosomal location found in our $P$. syringae pv. syringae strain 1392 is in agreement with a previous report (White and Ziegler 1991). However, the iaa $\mathrm{M} / i a a \mathrm{H}$ genes can also be located on plasmids, as observed in the oleander strains of $P$. savastanoi pv. savastanoi (Comai and Kosuge 1980). A similar location was observed for strains 2897 (P. syringae pv. 
myricae) and 2899 (2897 (P. syringae pv. photinae), where the probe obviously hybridized to plasmids. This result is consistent with the fact that plasmids often play an important role in plant-bacteria interactions, as exemplified by the detection of genes involved in the coronatine toxin production by strains of the $P$. syringae pvs. tomato and glycinea (Cuppels and Ainsworth 1995).

Results obtained in hybridization experiments performed with the iaa $\mathrm{L}$ probe vary according to the genomospecies. Hybridization of the probe with plasmids was observed in strains belonging to the genomospecies 2 . This was the case for at least 14 out of 17 strains that harbored plasmid(s) and in which the genome contained iaaL-related sequences. In contrast, plasmid-borne iaaL-related sequences were detected only in two strains of genomospecies 3 and in one strain of genomospecies 4. Interestingly, four out of the eight plasmids of the $P$. syringae pv. cannabina strain 2341 hybridized to the $i a a \mathrm{~L}$ probe. Hybridization of the $i a a \mathrm{~L}$ probe to multiple plasmids also occurred in several other strains. This latter phenomenon could be related to plasmid recombination such as co-integration or deletion, a hypothesis supported by the detection of numerous insertion sequences in plant-pathogenic Pseudomonas strains (Soby et al. 1993). The detection of iaaL-related sequences in strains of the $P$. syringae group is an interesting peculiarity of our study since it is the first time that such sequences have been widely detected in pathovars other than P. savastanoi pv. savastanoi. The synthesis of IAA-Lys, detected in culture supernatants of $P$. savastanoi pv. savastanoi strains (Hutzinger and Kosuge 1968; Glass and Kosuge 1986), supposedly regulates the amount of IAA produced by the bacteria, a feature that seems to be necessary for "optimal" growth of the strains in planta and the full expression of their virulence (Glass and Kosuge 1988; Surico and Iacobellis 1992). Overall, the results of the analysis of the plasmid content and of the location of the $i a a \mathrm{M}, i a a \mathrm{H}$, and $i a a \mathrm{~L}$ genes are in good agreement with those previously reported in the literature for a limited number of strains (Coplin 1982).

From the data presented above, auxin production is a common feature of most pathovars of $P$. syringae. Interestingly, our assayed strains clearly fall in two groups. The first group contains eight strains that produce high concentrations of IAA in the presence or absence of Trp and that harbor genes homologous to the $i a a \mathrm{M} / i a a \mathrm{H}$ genes of $P$. savastanoi. In agreement with the original results of Comai and Kosuge (1982) and White and Ziegler (1991) on P. savastanoi pv. savastanoi and $P$. syringae pv. syringae, we speculate that IAA synthesis in the strains of this first group involves the iaa $\mathrm{M} / i a a \mathrm{H}$ genes and therefore proceeds via indole- 3 acetamide (IAM). A second group, which contains most of the assayed strains, produces IAA but does not harbor genes highly related to the $i a a \mathrm{M} / i a a \mathrm{H}$ genes of $P$. savastanoi. IAA synthesis in this group of bacteria might be unspecific and result from the nonenzymic conversion of Trp to IAA in the culture medium: Epstein et al. (1980) showed that up to $30 \%$ of input Trp can be converted to IAA under certain experimental conditions. In our conditions, however, we never observed nonspecific conversion of Trp to IAA. Spontaneous transformation of Trp to IAA is also unlikely because several strains of the second group produce low but detectable amounts of IAA in the absence of added Trp in the medium. Furthermore, the conservation of the iaa $\mathrm{L}$ sequence in such strains would be more dif- ficult to understand if IAA production was only artefactual. Because we recently detected indole pyruvate (IPyrA) in the culture supernatants of strains of the second group and characterized an enzymic activity converting Trp to IPyrA (and vice-versa) in cell-free extracts of one of these strains (E. Glickmann, M. Elasri, A. Petit, and Y. Dessaux, unpublished), we suggest that IAA biosynthesis proceeds, at least in some isolates of the second group, via a pathway involving IPyrA as an intermediate, and not via IAM. Such a pathway has already been described in Azospirillum brasilense and Erwinia herbicola, which both produce IAA via IPyrA and indole acetaldehyde (Manulis et al. 1991; Costacurta et al. 1994; Brandl and Lindow 1996).

The involvement of IAA in pathogenicity has been unambiguously demonstrated for $P$. savastanoi pv. savastanoi. Interestingly, other pathovars such as $P$. syringae pv. amygdali and $P$. syringae pv. myricae, which induce proliferation of plant tissues on other host plants, also harbor iaa $\mathrm{M} / i a a \mathrm{H}$ genes. The reverse proposal, however, is not true. Various pathovars harboring the $i a a \mathrm{M} / i a a \mathrm{H}$ genes (e.g., $P$. syringae pvs. syringae, aceris, photinae, viburni, ribicola, and maculicola, and $P$. savastanoi pv. glycinea) do not induce proliferation of plant tissues, but rather necrotic diseases. Thus, pathogenicity in strains of $P$. savastanoi pv. glycinea and $P$. syringae pv. syringae relies on the presence and expression of the hrp genes (Huang et al. 1988; Lindgren et al. 1988; reviewed in Willis et al. 1991; Van Gijsegem et al. 1993; Bonas 1994). However, the latter strain is able to produce IAA at concentrations up to $70 \mu \mathrm{g} / \mathrm{ml}\left(4 \times 10^{-4} \mathrm{M}\right)$ in $\mathrm{KB}$ medium supplemented with 2.5 $\mathrm{mM}$ Trp. Very likely, these IAA concentrations are not produced in planta by most of the assayed Pseudomonas strains. However, even lower concentration of IAA could potentially induce biological effects. Previous studies performed with Pseudomonas strains suggested that IAA production by these strains may inhibit some plant defense mechanisms (Robinette and Matthysse 1990). IAA production also has been associated with the epiphytic survival of the bacteria or with toxin production as demonstrated for $P$. syringae pv. syringae strains on Phaseolus vulgaris (Mazzola and White 1994). These data, taken together with our results, demonstrate that the generalized production of IAA by plant-pathogenic Pseudomonas spp. might play various and substantial biological and ecological roles that remain to be elucidated.

\section{ACKNOWLEDGMENTS}

We thank Jean Dunez (INRA, Villenave d'Ornon, France) and François Blondon (CNRS, Gif-sur-Yvette) for their support and interest in this work, Angelo Spena (Max Planck Institut, Köln, Germany) for the gift of E. coli strain JM83(pLUC2) and that of plasmid pLG87, and Christian Jay-Allemand and Patrick Doumas (INRA, Orléans, France) for valuable advice on HPLC detection of IAA. E. G. was supported by a fellowship from the French Ministère de la Recherche et de la Technologie and by a fellowship from the Académie d'Agriculture de France. Parts of this work were presented at the 1eres Rencontres de Phytobacteriologie (Aussois, France, 1994) and at the Fifth International Conference on P. syringae pathovars (Berlin, 1995).

\section{LITERATURE CITED}

Ausubel F. M., Brent, R., Kingston, R. E., Moore, D. D., Seidman, J. G., Smith, J. A., and Struhl, K. 1989. Current Protocols in Molecular Biology. Greene Publishing Associates and Wiley-Interscience, John 
Wiley and Sons, New York.

Bonas, U. 1994. hrp genes of phytopathogenic bacteria. Pages 79-98 in: Bacterial Pathogenesis of Plants and Animals. J. L. Dangl, ed. Springer-Verlag, Berlin.

Brandl, M., and Lindow, S. E. 1996. Cloning and characterization of a locus encoding an indolepyruvate decarboxylase involved in indole-3acetic acid synthesis in Erwinia herbicola. Appl. Environ. Microbiol. 62:4121-4128.

Clark, E., Manulis, S., Ophir, Y., Barash, I., and Gafni, Y. 1993. Cloning and characterization of iaaM and iaaH from Erwinia herbicola pathovar gypsophilae. Phytopathology 83:234-240.

Comai, L., and Kosuge, T. 1980. Involvement of plasmid deoxyribonucleic acid in indoleacetic acid synthesis in Pseudomonas savastanoi. J. Bacteriol. 143:950-957.

Comai, L., and Kosuge, T. 1982. Cloning and characterization of iaaM, a virulence determinant of Pseudomonas savastanoi. J. Bacteriol. 149: 40-46.

Comai, L., Surico, G., and Kosuge, T. 1982. Relation of plasmid DNA to indoleacetic acid production in different strains of Pseudomonas syringae pv savastanoi. J. Gen. Microbiol. 128:2157-2163.

Coplin, D. L. 1982. Plasmids in plant pathogenic bacteria. Pages 255280 in: Phytopathogenic Prokaryotes. Vol. 2. M. S. Mount and G. H. Lacy, eds. Academic Press, San Diego, CA.

Costacurta, A., Keijers, V., and Vanderleyden, J. 1994. Molecular cloning and sequence analysis of an Azospirillum brasilense indole-3pyruvate decarboxylase gene. Mol. Gen. Genet. 243:463-472.

Cuppels, D. A., and Ainsworth, T. 1995. Molecular and physiological characterization of Pseudomonas syringae pv. tomato and Pseudomonas syringae pv. maculicola strains that produce the phytotoxin coronatine. Appl. Environ. Microbiol. 61:3530-3536.

Dessaux, Y., Elasri, M., Glickmann, E., Oger, P., Petit A., and Vaudequin-Dransart, V. 1995. The use of digoxigenin-labelled probes to detect DNA sequences specific for plant pathogenic bacteria. Cell. Mol. Biol. 41:933-943.

Dhaese, P., de Greve, H., Decraemer, H., Schell, J., and van Montagu, M. 1979. Rapid mapping of transposon insertion and deletion mutations in the large Ti plasmid of Agrobacterium tumefaciens. Nucleic Acid Res. 7:1837-1849.

Epstein, E., Cohen, J. D., and Bandurski, R. S. 1980. Concentration and metabolic turnover of indoles in germinating kernels of Zea mays L. Plant Physiol. 65:415-421.

Fett, W. F., Osman, S. F., and Dunn, M. F. 1987. Auxin production by plant-pathogenic pseudomonads and xanthomonads. Appl. Environ. Microbiol. 53:1839-1845.

Gardan, L., David, C., Morel, M., Glickmann, E., Abu-Ghorrah, M., Petit, A., and Dessaux, Y. 1992. Evidence for a correlation between auxin production and host plant species among strains of Pseudomonas syringae subsp. savastanoi. Appl. Environ. Microbiol. 58: 1780-1783

Gardan, L., Shafik, H. L., and Grimont, P. A. D. 1997. DNA relatedness among pathovars of $P$. syringae and related bacteria. Pages 445-452 in: Proc. Int. Conf. [on] Pseudomonas syringae Pathovars [and] Related Pathogens (Sept. 1995, Berlin), 5th. K. Rudolph, ed. Kluwer Academic Publishers, Dordrecht, The Netherlands.

Geniaux, E., Laguerre, G., and Amarger, N. 1993. Comparisons of geographically distant populations of Rhizobium isolated from root nodules of Phaseolus vulgaris. Mol. Ecol. 2:295-302 .

Gielen, J., De Beuckeleer, M., Seurinck, J., Deboeck, F., De Greve, H., Lemmers, M., Van Montagu, M., and Schell, J. 1984. The complete nucleotide sequence of the TL-DNA of the Agrobacterium tumefaciens plasmid pTiAch5. EMBO J. 3:835-846

Glass, N. L., and Kosuge, T. 1986. Cloning of the gene for indoleacetic acid-lysine synthetase from Pseudomonas syringae subsp. savastanoi. J. Bacteriol. 166:598-603.

Glass, N. L., and Kosuge, T. 1988. Role of indoleacetic acid-Lysine synthetase in regulation of indoleacetic acid pool size and virulence of Pseudomonas syringae subsp. savastanoi. J. Bacteriol. 170:23672373.

Gordon, S. A., and Weber, R. P. 1951. Colorimetric estimation of indoleacetic acid. Plant Physiol. 26:192-195.

Huang, H. C., Schuurink, R., Denny, T. P., Atkinson, M. M., Baker, C. J., Yucel, I., Hutcheson, S. W., and Collmer, A. 1988. Molecular cloning of a Pseudomonas syringae pv. syringae gene cluster that enables Pseudomonas fluorescens to elicit the hypersensitive response in tobacco plants. J. Bacteriol. 170:4748-4756

Hutzinger, O., and Kosuge, T. 1968. Microbial synthesis and degradation of indole-3-acetic acid. III. The isolation and characterization of indole-3-acetyl- $\varepsilon$-L-lysine. Biochemistry 7:601-605.

Johnson, J. L. 1984. Nucleic acids in bacterial classification. Pages 8-11 in: Bergey's Manual of Systematic Bacteriology. Vol. 1. N. R. Krieg and J. G. Holt, eds. Williams and Wilkins, Baltimore, MD.

King, E. O., Ward, M. K., and Raney, D. E. 1954. Two simple media for the demonstration of pyocyanin and fluorecin. J. Lab. Clin. Med. 44: 301-307.

Klee, H., Montoya, A., Horodyski, F., Lichtenstein, C., Garfinkel, D., Fuller, S., Flores, C., Peschon, J., Nester, E., and Gordon, M. 1984 Nucleotide sequence of the tms genes of the pTiA6NC octopine Ti plasmid: Two gene products involved in plant tumorigenesis. Proc. Natl. Acad. Sci. USA 81:1728-1732.

Kosuge, T., Heskett, M. G., and Wilson, E. E. 1966. Microbial synthesis and degradation of indole- 3 acetic acid. 1. The conversion of Ltryptophan to indole- 3 acetamide by an enzyme system from Pseudomonas savastanoi. J. Biol. Chem. 241:3738-3744.

Lindgren, P. B., Panopoulos, N. J., Staskawicz, B. J., and Dahlbeck, D. 1988. Genes required for pathogenicity and hypersensitivity are conserved and interchangeable among pathovars of Pseudomonas syringae. Mol. Gen. Genet. 211:499-506.

Liu, S. T., and Kado, C. I. 1979. Indoleacetic acid production: A plasmid function of Agrobacterium tumefaciens. Biochem. Biophys. Res. Commun. 90:171-178.

Manulis, S., Valinski, L., Gafni, Y., and Hershenborn, J. 1991. Indole-3acetic acid biosynthetic pathways in relation to pathogenicity on Gypsophila paniculata. Physiol. Mol. Plant Pathol. 39:161-171.

Mazzola, M., and White, F. F. 1994. A mutation in the indole-3-acetic acid biosynthesis pathway of Pseudomonas syringae pv. syringae affects growth in Phaseolus vulgaris and syringomycin production. J. Bacteriol. 176:1374-1382.

Nitsch, J. P., and Nitsch, C. 1956. Studies on the growth of coleoptile and first internode sections. A new, sensitive, straight-growth test for auxins. Plant Physiol. 31: 94-111.

Palm, C. J., Gaffney, T., and Kosuge, T. 1989. Cotranscription of genes encoding indoleacetic acid production in Pseudomonas syringae subsp. savastanoi. J. Bacteriol. 171:1002-1009.

Roberto, F. F., Klee, H., White, F., Nordeen, R., and Kosuge, T. 1990. Expression and fine structure of the gene encoding $\mathrm{N}-\varepsilon$-(indole-3acetyl)-L-lysine synthetase from Pseudomonas savastanoi. Proc. Natl. Acad. Sci. USA 87:5797-5801.

Robinette, D., and Matthysse, A. G. 1990. Inhibition by Agrobacterium tumefaciens and Pseudomonas savastanoi of development of the hypersensitive response elicited by Pseudomonas syringae pv. phaseolicola. J. Bacteriol. 172:5742-5749.

Sambrook, J., Fritsch, E. R., and Maniatis, T. A. 1989. Molecular Cloning: A Laboratory Manual. 2nd ed. Cold Spring Harbor Laboratory, Cold Spring Harbor, NY.

Schaad, N. W. 1982. How phytopathogenic prokaryotes are classified. Pages 19-29 in: Phytopathogenic Prokaryotes. Vol. 1. M. S. Mount and G. H. Lacy, eds. Academic Press, San Diego, CA.

Smidt, M., and Kosuge, T. 1978. The role of indole-3-acetic acid accumulation by alpha methyl tryptophan-resistant mutants of Pseudomonas savastanoi in gall formation on oleanders. Physiol. Plant $\mathrm{Pa}-$ thol. 13:203-214

Sneath, P. H. A. 1984. Numerical taxonomy. Pages 5-7 in: Bergey's Manual of Systematic Bacteriology. Vol. 1. N. R. Krieg and J. G. Holt, eds. Williams and Wilkins, Baltimore, MD.

Soby, S., Kirkpatrick, B., and Kosuge, T. 1993. Characterization of an insertion sequence (IS 53) located within IS51 on the iaa-containing plasmid of Pseudomonas syringae pv. savastanoi. Plasmid 29:135141.

Surico, G., and Iacobellis, N. S. 1992. Phytohormones and olive knot disease. Pages 209-227 in: Molecular Signals in Plant Microbe Communications. D. P. S. Verma, ed. CRC Press, Boca Raton, FL.

Van Gijsegem, F., Genin, S., and Boucher, C. 1993. Conservation of secretion pathways for pathogenic determinants of plants and animal bacteria. Trends Microbiol. 1:175-180.

Vaudequin-Dransart, V., Petit, A., Poncet, C., Ponsonnet, C., Nesme, X. Jones, J. B., Bouzar, H., Chilton, W. S., and Dessaux, Y. 1995. Novel Ti plasmids in Agrobacterium strains isolated from fig tree and chrysanthemum tumors and their opinelike molecules. Mol. Plant-Microbe 
Interact. 8:311-321.

Wayne, L. G., Brenner, D. J., Colwell, R. R., Grimont, P. A. D., and Kandler, O. 1987. Report of the ad hoc committee on reconciliation of approaches to bacterial systematics. Int. J. Syst. Bacteriol. 37:463464.

Wheatcroft, R., McRae, D. G., and Miller, R. W. 1990. Changes in the Rhizobium meliloti genome and the ability to detect supercoiled plasmids during bacteroid development. Mol. Plant-Microbe Interact. 3:917.

White, F. F., and Ziegler, S. F. 1991. Cloning of the genes for indoleacetic acid synthesis from Pseudomonas syringae pv. syringae. Mol. Plant-Microbe Interact. 4:207-210.

Willis, D. K., Rich, J. J., and Hrabak, E. M. 1991. hrp genes of phytopathogenic bacteria. Mol. Plant-Microbe Interact. 4:132-138.

Wilson, E. E. 1935. The olive knot disease: Its inception, development and control. Hilgardia 9:231-264.
Woese, C. R. 1992. Prokaryote systematics: The evolution of a science. Pages 3-18 in: The Prokaryotes. A. Balows, ed. Springer-Verlag, Berlin.

Yamada, T., Palm, C. J., Brooks, B., and Kosuge, T. 1985. Nucleotide sequence of the Pseudomonas savastanoi indoleacetic genes and homology with Agrobacterium tumefaciens T-DNA. Proc. Natl. Acad. Sci. USA 82:6522-6526.

Young, J. M., Saddler, G. S., Takikawa, Y., De Boer, S. H., Vauterin, L., Gardan, L., Gvozdyak, R. I., and Stead, D. E. 1996. Names of plant pathogenic bacteria 1864-1995. Rev. Plant Pathol. 75:721-763.

Young, J. M., Takikawa, Y., Gardan, L., and Stead, D. E. 1992. Changing concepts in the taxonomy of plant pathogenic bacteria. Annu. Rev. Phytopathol. 30:67-105.

Ziegler, S. F., White, F. F., and Nester, E. W. 1987. Genes involved in indole acetic acid production in plant pathogenic bacteria. Proc. Int. Conf. [on] Plant Pathogenic Bacteria, 6th. Martinus-Nijhoff, Dordrecht, The Netherlands. 